\title{
Physicochemical Properties of the Fermentation of Poly Hydroxy Acid (PHA) using the Lactobacillus plantarum J2K-27 Strain
}

\author{
Mikyung Sung ${ }^{1}$, Jungwook Kang ${ }^{2}$, Kitae Bang ${ }^{1}$, Jinhyun $\mathrm{Kim}^{1}$, Inyoung $\mathrm{Na}^{1}$, Hungi Seo ${ }^{1}$, Kyeongseok So ${ }^{1,3}$, Taehoon Kim ${ }^{1}$, Youngkwon Cha ${ }^{1}$, \\ Hyundae $\mathrm{Cho}^{1}$, Hangeui Cho ${ }^{1,3^{*}}$ \\ ${ }^{1}$ Creative Innovation Research Center, Cosmecca Korea, Co. Ltd., Seongnam-si, Gyeonggi-do, Korea \\ ${ }^{2}$ Industry-Academic Collaboration Foundation, Seowon University, Cheongju, Chungcheongbuk-do, Korea \\ ${ }^{3}$ Department of Cosmetics Engineering, Konkuk University, Seoul, Korea
}

\author{
*Corresponding author: Hangeui Cho, \\ Cosmecca Korea, Co. Ltd., 6th Floor, \\ ABN Tower, 331 Pangyo-ro, Bundang-gu, \\ Seongnam-si, Gyeonggi-do 13488, Korea \\ Tel.: +82 27846551 \\ Fax: +82 26282290 \\ Email: bioche1975@cosmecca.com
}

Mikyung Sung and Jungwook Kang contributed equally to this work.

Received February 9, 2021

Revised April 15, 2021

Accepted April 16, 2021

Published June 30, 2021

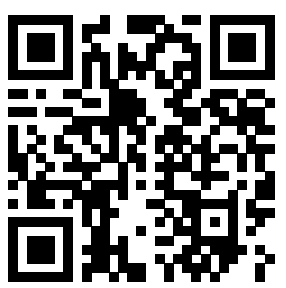

\begin{abstract}
Purpose: This study aimed to investigate the characteristics of fermented poly hydroxyl acid (F-PHA) using the Lactobacillus plantarum J2K-27 strain, and identify the applicability of its biological compounds. Methods: F-PHA was analyzed using high-performance liquid chromatography (HPLC) to identify its active compounds. Furthermore, the radical scavenging activities were evaluated for F-PHA. The cell viability and expression of procollagen type 1 and hyaluronic acid were investigated. Results: Changes in F-PHA represented the increase of lactobionic acid and lactic acid after fermentation. F-PHA increased radical scavenging activity in a dosedependent manner. After fermentation, F-PHA was confirmed to increase the expression of procollagen type 1 synthesis and hyaluronic acid without cytotoxicity. Conclusion: These results confirmed that F-PHA shows generally higher activities functional cosmetic material.
\end{abstract}

Keywords: Poly hydroxyl acid, Lactobionic acid, Lactic acid, Fermentation, Cosmetic materials

\section{Introduction}

하이드록시산(hydroxyl acid, HA)은 화장품에서 각질 박리제로 서 많이 사용되는 성분으로, 글라이콜릭산(glycolic acid)을 주성분으 로 하는 알파하이드록시산(alpha hydroxy acid, AHA)과 살리실산 (salicylic acid)인 베타하이드록시산(beta hydroxy acid, BHA)이 있 다(Bashir et al., 2005). AHA는 수용성으로 피부 각질을 연화 시 켜 탈락을 유도하여 피부의 각질을 녹여내는 특징을 나타내며, $\mathrm{BHA}$ 는 지용성 성분으로 여드름이나 블랙헤드 부분에 각질을 제거하 여 피지분비가 왕성한 지성 피부나 여드름성 피부에 주로 사용된다 (Tang \& Yang, 2018). 그러나 이 두 가지 성분은 비교적 높은 농도 를 사용할 시에 분자크기가 작아 피부에 빠르게 침투되기 때문에 사
람들이 자극을 느끼는 경우가 많으며, 사용 직후 피부 장벽 손상, 보 습력 감소, 홍반 유발 등의 단점이 있다(Grimes et al., 2004; Kim $\&$ Choi, 2018). 최근 들어 $\mathrm{AHA}, \mathrm{BHA}$ 의 이러한 단점을 보완한 폴리 하이드록시산(poly hydroxy acid, PHA) 성분은 복합적인 hydroxy groups을 가지고 있기 때문에 일반적인 $\mathrm{AHA}$ 보다 더욱더 효과적이 고 강력한 보습력을 가지고 있다(Algiert-Zielińska et al., 2018). 또 한 lactobionic acid는 피부에서 수분 함유력이 뛰어난 글루코사미노 글라이칸(glycosaminoglycans, GAG)의 합성을 촉진시킨다. $\mathrm{PHA}$ 는 $\mathrm{AHA}$ 와 $\mathrm{BHA}$ 에 비해 분자 크기가 커서 피부에 빠르게 침투하지 않아 자극이 적을 뿐만 아니라 필링제로 보습효과가 뛰어나고 항산화 효과 도 우수하다(Edison et al., 2004; Tasic-Kostov et al., 2010).

발효는 천연물이 가진 성분이나 소재의 활용성을 증진시키기 위해 
유산균 등의 미생물을 이용하여 배양하여 효능을 증진시키는데 이용 되어 왔다(Tesfaye et al., 2002). 유산균, 효모 등의 미생물을 이용 한 발효 기술을 통해 다당체, 폴리페놀, 아미노산 펩타이드 등의 발 효 산물을 생성하거나 상승 작용에 의해 항산화, 항노화, 미백 등의 생리활성 효능이 나타난다고 보고되었다(Kim \& Kim, 2015; Park et al., 2019). 특히, Lactobacillus sp. 등의 유산균을 이용한 발효 배양은 항산화 및 항노화 등에 효능이 나타난다고 보고되고 있으며, $\beta$-glucosidase 활성을 가지고 있어 배당체의 장내가수분해에 관여한 다고 알려져 있다(Song et al., 2020: Tsukahara et al., 2009). 황기, 동충화초 등을 발효배양하여 미생물의 효소를 이용하여 유기물을 분 해 및 변화시켜 이화학적 특징을 가지는 연구가 보고되었다(Um et al., 2017; Ahn et al., 2013). 특히, 이중발효(double fermentation) 는 식품을 이용한 발효물에서 자연스럽게 관찰할 수 있으며 에탄올과 같은 특정 부산물을 싸고 빠르게 수득하기 위하여 특수하게 고안되기 도 한다(Pervez et al., 2014; Pinto et al., 2015).

본 연구에서는 천연물 발효를 통하여 유용한 부산물들을 얻는 과 정과 유사하지만 동시에 일정한 부산물을 지속적으로 얻기 위하여 Lactobacillus plantarum J2K-27을 순차적으로 두 번 발효하는 과 정을 통해 F-PHA 발효물을 제조한 후 기능성 화장품 소재로서의 가 능성을 확인하였다.

\section{Methods}

\section{1. 발효 균주}

발효를 위해 사용한 균주는 $\mathrm{J} 2 \mathrm{KBIO}$ 에서 분리 및 동정한 Lactobacillus plantarum J2K-27 (KCTC 13696BP)를 사용하였 다. 이 균주를 배양하기 위해 de Man, Rogosa and Sharpe (MRS; Difco, USA) 배지를 사용하여 배양하였으며, 발효균을 MRS broth를 이용하여 진탕배양기(HB-201S; Hanbaek, Korea) $37^{\circ} \mathrm{C}$ 에서 120 $\mathrm{rpm}$ 으로 $48 \mathrm{~h}$ 전배양하였다.

\section{2. 발효물 제조}

본 실험에서 사용한 배지는 MRS 배지에 lactobionic acid $0.1 \%$ 를 첨가하고, 전배양액을 $5 \%$ 접종하여 사용하였다. 배양은 $37^{\circ} \mathrm{C}$ 에서 $120 \mathrm{rpm}$ 으로 $48 \mathrm{~h}$ 배양하여 발효액을 제조하였고, 발효 후 10,000 rpm으로 원심분리기(1580R; LABOGENE, Korea)를 $15 \mathrm{~min}$ 간 진 행하였다. 이후 $0.45 \mu \mathrm{m}$ 여과지(Millipore, USA)을 이용하여 여과 후에 $60^{\circ} \mathrm{C}$ 에서 진공농축기(Rotavapor ${ }^{\circledR} \mathrm{R}-300$; $\left.\mathrm{BUCHI}, \mathrm{SWISS}\right)$ 를 이용하여 농축하였다.

\section{HPLC 분석}

발효 추출물 내의 lactobionic acid와 lactic acid 함량을 확인하 기 위하여 고성능 액체크로마토그래피(high performance liquid chromatography, HPLC, e2695; Waters, USA) 분석을 진행하였 다. 표준 물질인 lactobionic acid (Sigma-Aldrich, USA)와 lactic acid (Sigma-Aldrich), 시험 물질인 발효물을 정제수로 희석하 여 $0.45 \mu \mathrm{m}$ 필터로 여과하여 사용하였다. HPLC 분석은 Waters Alliance e2695 기기의 검출기 Waters $2998 \mathrm{PDA}$ 를 사용하였다. 분 석에 사용된 컬럼은 YMC-Triart C18 (3.0 X $150 \mathrm{~mm}$; YMC Co., Korea) 컬럼을 사용하였고, 컬럼온도는 $35^{\circ} \mathrm{C}$ 로 유지하였다. 유속은 $0.425 \mathrm{~mL} / \mathrm{min}$, 주입량은 $20 \mu \mathrm{L}$ 였다. 이동상은 메탄올(DaeJung Chemical Metals, Korea) (a)과 $20 \mathrm{mM}$ phosphoric acid (DaeJung Chemical Metals) (b)를 사용하였으며 상세 용매조건으로는 메탄올 $3 \%, 20 \mathrm{mM}$ phosphoric acid $97 \%$ 로 하여 $220 \mathrm{~nm}$ 에서 검출하였다.

\section{4. $\mathrm{DPPH}$ 소거능 평가}

96 well immunoplate에 $50 \%$ 에탄올에 용해시킨 후, $0.25 .0 .5,1$, $2 \%$ 농도의 시험물질을 $160 \mu \mathrm{L}$ 씩 분주한 후 $1 \mathrm{mM} \mathrm{2,2-diphenyl-}$ 1-picrylhydrazyl (DPPH; Alfa Aesar, USA) 시약을 $40 \mu \mathrm{L}$ 씩 넣 어 상온에서 $30 \mathrm{~min}$ 간 반응하였다. Microplate reader (GM3000; Promega, USA)를 이용하여 $490 \mathrm{~nm}$ 에서 흡광도를 측정하여 DPPH 소거능을 계산하였다. 시험의 양성 대조군으로는 ascorbic acid (Sigma-Aldrich)를 사용하였다.

\section{5. 세포 배양}

인체각질세포(human keratinocyte)인 $\mathrm{HaCaT}$ 세포를 페니실린 과 스트렙토마이신(WELGENE, Korea), $10 \%$ fetal bovine serum (FBS; Thermo Fisher Scientific, USA)를 함유하는 Dulbecco's Modified Eagle's Medium (DMEM; Thermo Fisher Scientific) 배지 에 넣고 $37^{\circ} \mathrm{C}, 5 \%$ 이산화탄소를 포함하는 배양기(FORMA STERICYCLE 371; Thermo Fisher Scientific)내에서 배양하였다.

인체섬유아세포(human fibroblast)를 페니실린과 스트렙토마이 신, 보조제(supplement)를 함유하는 fibroblast basal medium (FBM; LONZA, Switzerland) 배지에 넣고 $37^{\circ} \mathrm{C}, 5 \%$ 이산화탄소를 포함하 는 배양기내에서 배양하였다.

\section{6. 세포 생존율}

96 well plate에 HaCaT 세포를 $1.5 \times 10^{4}$ cells/well씩 분주한 후, $24 \mathrm{~h}$ 동안 세포가 plate에 잘 붙도록 $37^{\circ} \mathrm{C}, 5 \% \mathrm{CO}_{2}$ 세포 배양기에 배 양하였다. $24 \mathrm{~h}$ 후, 배양액을 버리고 $\mathrm{PBS}$ 로 세척한 다음 $\mathrm{FBS}$ 를 포 함하지 않은 DMEM 배지를 사용하여 세포를 기아상태로 만들어 주 었다. 다음 날, 일정 농도의 시험물질을 처리하여 $24 \mathrm{~h}$ 배양하였다. 배지에 10 배 희석시킨 WST-1 시약(Dogenbio, Korea)을 각 well에 $100 \mu \mathrm{L}$ 씩 넣고 $2 \mathrm{~h}$ 배양 후, Microplate reader를 이용하여 $450 \mathrm{~nm}$ 에서 흡광도를 측정하였다.

세포생존율 $(\%)=$ 시료첨가군의 흡광도 $/$ 대조군의 흡광도 $\times 100$ 
A

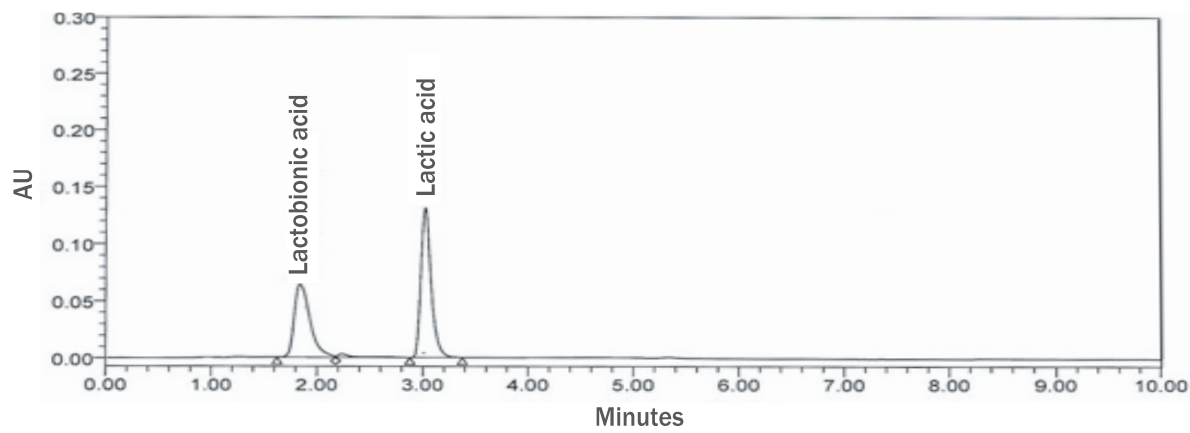

B

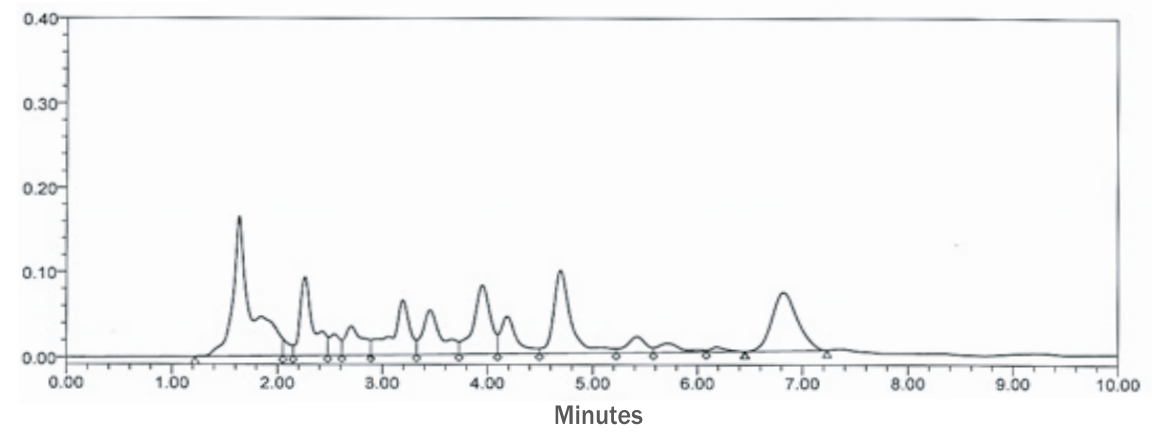

C

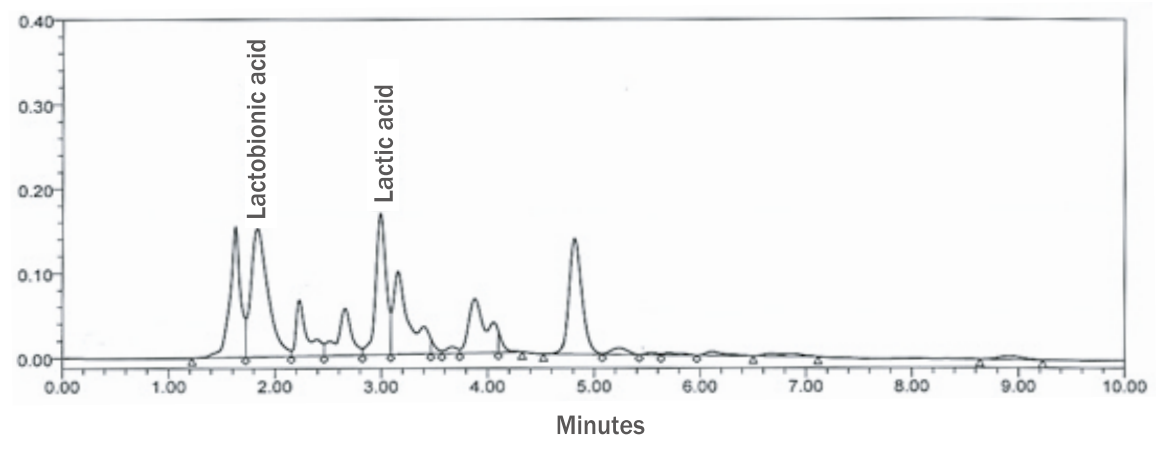

Figure 1. HPLC analysis of F-PHA.

F-PHA after fermentation. A waters 2998 photodiode array (PDA) detector was used for the HPLC analysis of lactobionic acid, lactic acid, and F-PHA. Methanol and $20 \mathrm{mM}$ phosphoric acid were used as the mobile phase, and YMC-Triart C18 was used as the column to separate the molecules.

\section{7. 히알루론산(hyaluronic acid, $\mathrm{HA}$ ) 생성량 측정}

96 well plate에 $\mathrm{HaCaT}$ 세포를 $1.5 \times 10^{4}$ cells/well씩 분주한 후, 세포 배양조건에서 배양하였다. $24 \mathrm{~h}$ 후, 배양액을 버리고 PBS로 세척한 다음 FBS를 함유하지 않은 DMEM 배지를 사용하여 세포 를 기아상태로 만들어주었다. 다음 날, 일정 농도의 시험물질을 처 리하여 $24 \mathrm{~h}$ 배양하였다. 히알루론산 ELISA kit (R\&D System, USA)를 이용하여 실험 후, Microplate reader를 이용하여 $450 \mathrm{~nm}$ 에서 흡광도를 측정하였다. 최종 히알루론산의 양은 일정 단백질 당 히알루론산의 양으로 환산하여 음성대조군과 비교하였다. 시험 의 양성 대조군으로는 retinoic acid (Sigma-Aldrich)를 사용하였 다.

\section{8. 프로콜라겐(procollagen) type 1 생성량 측정}

96 well plate에 인체섬유아세포를 $6 \times 10^{3}$ cells/well씩 분주한 후, 세포 배양조건에서 배양하였다. $24 \mathrm{~h}$ 후, 배양액을 버리고 PBS 로 세척한 다음 보조제를 함유하지 않은 FBM 배지를 사용하여 세포 를 기아상태로 만들어주었다. 다음 날, 일정 농도의 시험물질을 처 리하여 $24 \mathrm{~h}$ 배양하였다. 프로콜라겐 type 1 ELISA kit (TAKARA, Japan)를 이용하여 실험 후, Microplate reader를 이용하여 450 $\mathrm{nm}$ 에서 흡광도를 측정하였다. 최종 프로콜라겐 type 1 의 양은 일정 단백질 당 프로콜라겐 type 1 양으로 환산하여 음성대조군과 비교하 였다. 시험의 양성 대조군으로는 TGF- $\beta$ (PeproTech, USA)를 사용 하였다. 


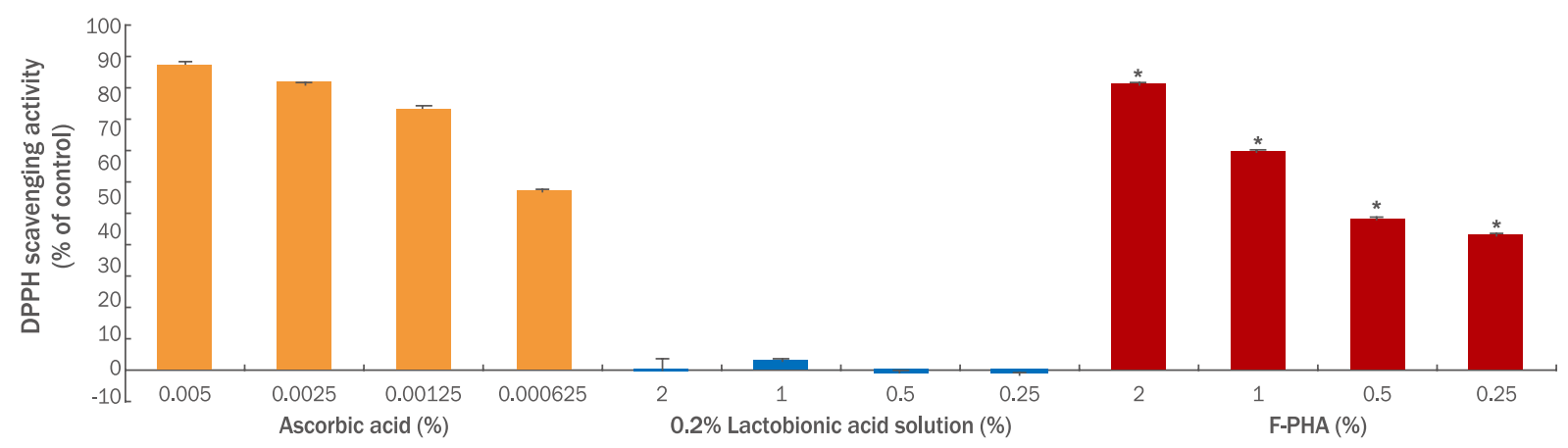

Figure 2. DPPH radical scavenging activity of F-PHA.

About $160 \mu \mathrm{L}$ of various concentrations (from $0.25 \%$ to $2 \%$ ) of $0.2 \%$ lactobionic acid solution and F-PHA were added to $40 \mu \mathrm{L}$ of $1 \mathrm{mM}$ DPPH solution. The plate was incubated for $30 \mathrm{~min}$ at ambient temperature, and the absorbance was recorded at $490 \mathrm{~nm}$ using a spectrophotometer. ${ }^{*} p<0.001$, significantly different compared to control.

\section{9. 통계처리}

본 실험에서 얻은 결과값은 평균값(mean)과 표준편차(standard deviation, S.D)로 나타내었다. 대조군과 실험군 사이의 통계학적 유 의성 검정은 Student's $t$-test로 비교하였으며 $p$-value 값이 0.05 미 만일 경우 통계적으로 유의한 것으로 평가하였다

\section{Results and Discussion}

\section{HPLC 분석}

이중발효 통해 제조된 발효물의 lactobionic acid 함량을 확인하고 자 고성능 액체 크로마토그래프 실험을 진행하였다. 분석 결과, 발효 전 배지에서는 확인되지 않은 peak가 발효 후에 생성되는 것을 확인 하였으며 표준물질인 lactobionic acid와 lactic acid의 peak retention time을 비교하여 동일 물질임을 확인하였다(Figure 1). 발효물 내에 lactobionic acid는 $0.2 \%$, lactic acid는 $0.1 \%$ 로 함유되어 있는 것으로 나타났다. Lactobionic acid 생산 균주로 1차 발효를 통해 lactose 이 당류로부터 미생물이 생성하는 효소 촉매 반응으로 lactobionic acid 가 생성되며, 생성된 lactobionic acid에 분리동정한 프로바이오틱스 유산균 발효 배양으로 2 차 발효를 진행하였다. 2 차 발효 전에 $0.1 \%$ 였던 lactobionic acid 함량이 2 차 발효를 통해 2 배 증가하여 $0.2 \%$ 로 측정되었다. 이중발효를 통해 lactibionic acid 함량을 증가시킬 뿐 아 니라 lactic acid를 포함한 발효 산물이 생성되어 피부 효능에 시너지 효과를 부여할 수 있을 것으로 기대된다. 또한 발효 전과 비교하여 발효 후에 생성된 신규 물질에 대해서는 성분 규명을 위한 추가 연구 가 필요하다.

\section{DPPH 소거능 효과}

안정한 자유 라디칼인 $\mathrm{DPPH}$ 를 이용하여 라디칼이 소멸되는 정
도를 측정하여 간접적으로 항산화 활성을 평가하였다(Foti, 2015; Kang et al, , 2019).

Lacticbionic acid를 $\mathrm{F}-\mathrm{PHA}$ 에 함유되어있는 함량과 동일하게 $0.2 \%$ 의 용액으로 제조하여 시료로 사용하였으며 각 시험물질의 농도 를 $0.25,0.5,1,2 \%$ 로 선정하여 $\mathrm{DPPH}$ 소거능 평가를 진행하였다. $0.2 \%$ lactobionic acid 용액은 DPPH 소거능이 없는 것으로 나타났으 며 $\mathrm{F}-\mathrm{PHA}$ 는 농도 의존적으로 $\mathrm{DPPH}$ 를 소거하는 것으로 나타났다 (Figure 2). $\mathrm{F}-\mathrm{PHA}$ 의 $\mathrm{IC}_{50}$ 값은 $0.67 \%$ 로 매우 우수한 항산화 효과 가 있는 것을 확인하였다.

Tasic-Kostov et al. (2010) 연구에서 lactobionic acid의 $\mathrm{IC}_{50}$ 값은 약 5.263\%로 나왔으며, 이와 비교하여 $0.2 \%$ lactobionic acid 용액 과 F-PHA를 최고 $2 \%$ 처리하였을 경우에 함유되어 있는 lactobionic acid 함량은 $0.004 \%$ 로 매우 낮은 농도였다. $0.2 \%$ lactobionic acid 용 액은 함유되어 있는 lactobionic acid 함량이 낮아 DPPH 소거능 효과 가 없으며 F-PHA는 이중 발효를 통해 동일한 lactobionic acid를 함 유하면서 우수한 항산화 효과가 있는 기능성 화장품 소재로서 가능성 이 있음을 확인하였다. $\mathrm{F}-\mathrm{PHA}$ 의 DPPH 소거능 활성은 lactobionic acid에 의한 것이 아닌 발효 신규 물질에 의한 것으로 해석된다.

\section{3. 세포독성}

WST-1은 세포 내의 미토콘드리아 탈수소효소에 의해 tetrazolium salts에서 formazan이라는 발색 물질의 생성 정도를 측정하여 세포 증식 능력 또는 생존 능력을 정량화하는 시험법이다 (Ngamwongsatit et al., 2008). F-PHA에 대한 피부 효능 시험을 진행하기에 앞서 세포 독성 여부를 확인하고자 시험을 진행하였다. Lactobionic acid를 F-PHA에 함유되어있는 함량과 동일하게 $0.2 \%$ 의 용액으로 제조하여 시료로 사용하였으며 시험 물질의 용액을 최소 $0.625 \%$ 부터 최고 $5 \%$ 까지의 농도로 하여 세포에 처리한 후, WST -1 시약을 이용하여 세포 생존율을 측정하였다. 
A

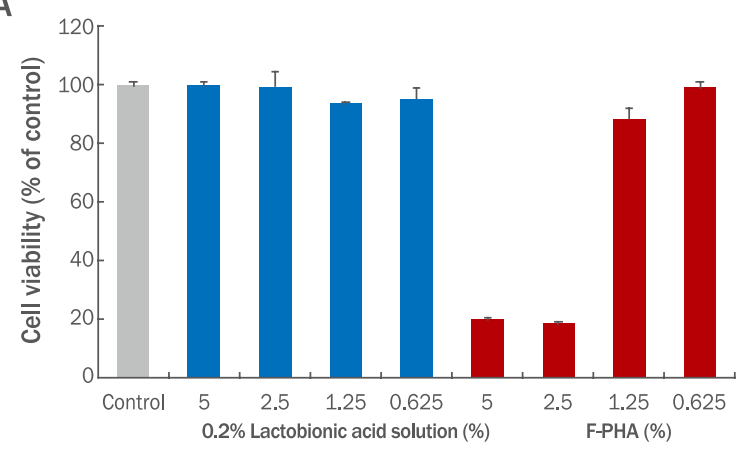

B

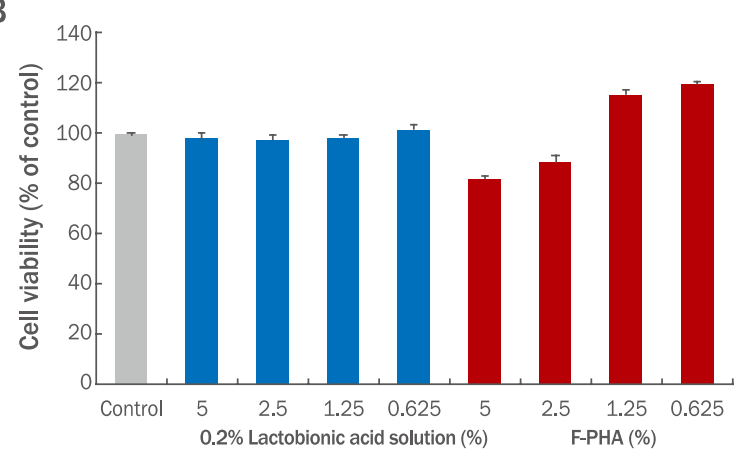

Figure 3. Cell viability of F-PHA on (A) human dermal fibroblasts and (B) HaCaT.

Human dermal fibroblasts $\left(6 \times 10^{3}\right.$ cells/well) and HaCaT (1.5x $10^{4}$ cells/well) were seeded in a 96-well plate and treated with the same concentration of lactobionic acid and F-PHA for $24 \mathrm{~h}$. The WST-1 assay kit was used to perform the cell viability assay. The results are the mean $\pm S D$ of the percentage of control. SD, standard deviation.

$0.2 \%$ lactobionic acid 용액은 인체섬유아세포, $\mathrm{HaCaT}$ 세포 모두 최고 5\%에서도 세포독성이 나타나지 않았으며, F-PHA는 인체섬유 아세포에서 최고 $0.625 \%, \mathrm{HaCaT}$ 에서 최고 $1.25 \%$ 의 농도에서 세포 독성이 나타나지 않았다(Figure 3). 본 효능 시험의 농도는 세포 독성 이 없는 공통의 농도 2 개 또는 3 개를 선정하여 효력의 농도 의존성을 확인하였다.

F-PHA가 동일 농도의 lactobionic acid 용액보다 세포 독성이 높 은 것으로 나타나는데, 이는 발효를 통해 lactobionic acid 외의 발효 산물들에 의해 독성이 발생한 것으로 생각되며, 독성이 없는 저농도 에서 피부 효능이 확인되면 기능성 소재로서의 안전성 문제는 없을 것으로 생각된다.

\section{4. 프로콜라겐 type-1 생성 촉진 효과}

피부 진피에 있는 섬유아세포는 프로콜라겐을 생성하며 효소반응 을 거쳐 최종 콜라겐 섬유로 완성된다. 이렇게 생성된 콜라겐은 피부 의 유연성, 탄력성 등을 유지하는 역할을 하며 콜라겐이 부족해지면

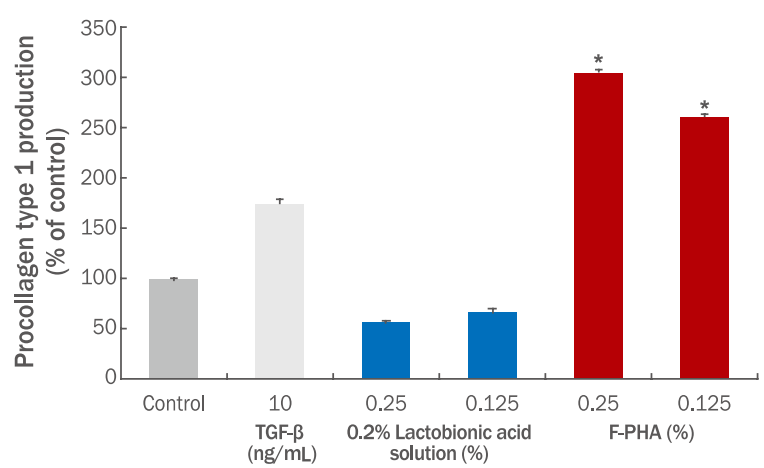

Figure 4. Procollagen type 1 synthesis-promoting effects of F-PHA.

Human dermal fibroblasts $\left(6 \times 10^{3}\right.$ cells/well) were seeded in a 96-well plate and treated with the same concentration of $0.2 \%$ lactobionic acid solution and F-PHA for $24 \mathrm{~h}$. TGF- $\beta$ was used as a positive control. The procollagen assay kit was conducted to evaluate procollagen production. The results are the mean $\pm S D$ of the percentage of control. ${ }^{*} p<0.001$, significantly different compared to control.

피부 주름이 발생하는 노화가 유발된다(Varani et al., 2001). 피부 콜라겐 중 대부분을 차지하는 것은 type- 1 콜라겐으로, 인체섬유아 세포 내 프로콜라겐 type-1의 생성량 측정을 통해 항노화 효능을 평 가하였다(Jo et al., 2012; Kim et al., 2003; Yang \& Kwak, 2016).

각 시험물질의 농도는 $0.125,0.25 \%$ 로 선정하여 인체섬유아세포 에 처리하였다. $0.2 \%$ lactobionic acid 용액은 아무런 효과가 없는 것 이 비해 F-PHA에서는 농도 의존적으로 프로콜라겐 type- 1 생성량 이 증가하였다(Figure 4). 증가한 프로콜라겐의 양은 음성 대조군 대 비 최소 $161.4 \%$ 에서 최고 $206.0 \%$ 로 나타났다. 이는 F-PHA가 피부 세포의 프로콜라겐 type- 1 생성을 증가시켜 주름을 억제하는 항노화 효과가 있음을 의미한다.

프로콜라겐 type- 1 생성 촉진효과가 있던 $0.25 \%$ 의 F-PHA 안 에 함유된 lactobionic acid의 함량은 $0.0005 \%$ 로, lactobionic acid 단 독으로 프로콜라겐 type-1 생성 촉진 효과가 있기에는 매우 낮은 함 량이다. Lactobionic acid가 8\% 함유된 제형은 주름 개선의 노화 방 지 효과가 있으며 피부 내 MMP-9 효소의 활동 감소로 광노화를 예 방한다고도 알려져 있다(Green et al., 2008). F-PHA는 lactobionic acid보다 낮은 함량으로 유사한 주름개선의 항노화 효과가 나타날 것 으로 기대한다.

\section{5. 히알루론산 생성 촉진 효과}

히알루론산은 탁월한 보습능력이 있는 물질로, 함습성에 의해 외 부의 수분을 끌어당겨 피부 안에 수분을 붙잡아 준다. 이를 통해 건 조함을 방지하여 피부 손상을 억제하고, 피부의 탄력과 보습을 유지 시켜주는 성분이다. 피부 세포 내 히알루론산의 생성량 측정을 통해 보습 효능을 평가하였다(Kim et al., 2018; Lee et al., 2020). 


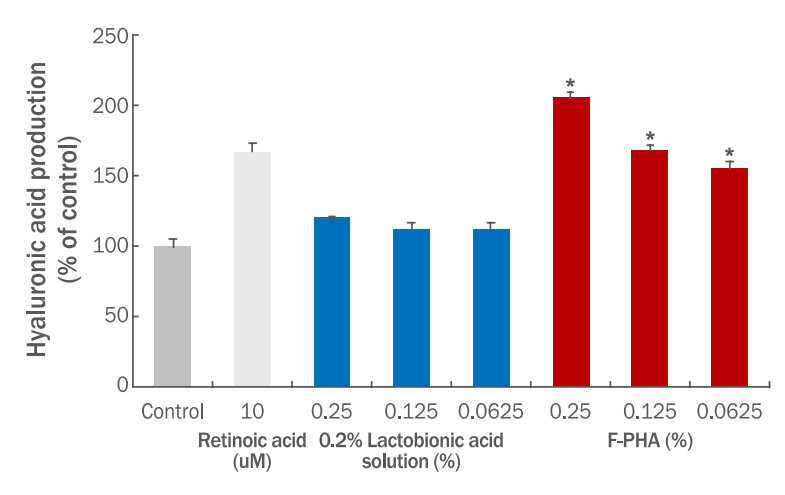

Figure 5. Hyaluronic acid synthesis-promoting effects of F-PHA. HaCaT $\left(1.5 \times 10^{4}\right.$ cells/well) were seeded in a 96-well plate and treated with the same concentration of $0.2 \%$ lactobionic acid solution and F-PHA for $24 \mathrm{~h}$. Retinoic acid was used as a positive control. The hyaluronic acid kit was conducted to evaluate hyaluronic acid production. The results are the mean \pm SD of the percentage of control. * $p<0.001$, significantly different compared to control.

각 시험물질의 농도는 $0.0625,0.125,0.25 \%$ 로 선정하여 $\mathrm{HaCaT}$ 세포에 처리하였다. $0.2 \%$ lactobionic acid 용액은 아무런 효과가 없 는 것이 비해 F-PHA에서는 농도 의존적으로 히알루론산의 생성량 이 증가하였다(Figure 5). 증가한 히알루론산의 양은 음성 대조군 대 비 최소 $56.0 \%$ 에서 최고 $106.0 \%$ 로 나타났다. F-PHA에 함유되어 있는 lactobionic acid은 피부 세포 내 히알루론산 생성 촉진 효과를 나타내기에 매우 낮은 농도로 lactobionic acid만을 동일 농도로 처리 하였을 때에 효과가 없는 것으로 나타났다.

Lactobionic acid는 물분자와 결합하여 수분공급 능력이 우수한 보습 성분으로 F-PHA에 함유되어 있는 lactobionic acid의 효과와 $\mathrm{F}-\mathrm{PHA}$ 의 발효 물질의 세포 내 히알루론산 생성 촉진 효과가 시너지 효과를 내어 lactobionic acid 단독 사용보다 우수한 보습효과를 가지 며 피부 건조를 방지하여 피부 손상을 억제해준다는 것으로 기대된다.

\section{Conclusion}

본 연구는 프로바이오틱스 유산균을 이중발효하여 lactobionic $\mathrm{acid}$ 를 함유하면서 피부 효능을 가지는 기능성 화장품 소재를 개발 하고자 하였다. 이중발효는 식품, 화장품 산업에서 사용하는 방법으 로 아미노산, 단백질 등 유효 성분의 함량 극대화, 발효의 특이 취 등 의 성질 제거, 흡수율 증대 등을 위해 사용한다. Lactobionic acid 함 량 증대, 신규 발효 산물 및 부가적인 피부 효능을 위해 이러한 이중 발효 공법을 적용하였다. Lactobionic aicd 생성 균주로 1차 발효를 통해 lactose 이당류로부터 미생물이 생성하는 효소 촉매 반응으로 lactobionic acid 생성 후, 분리 동정한 프로바이오틱스 Lactobacillus plantarum로 2차 발효를 진행하여 lactobionic acid를 함유한 발효 물을 제조할 수 있었다. 제조된 발효물의 지표물질 함량 측정과 피부 효능 평가를 통해 기능성 소재로서의 가능성을 확인하고자 하였다.

고성능 액체 크로마토그래프를 통해 발효 전과 발효 후 새로운 산물이 발생하는 것을 peak의 변화를 통해 확인할 수 있었으며, lactobionic acid는 $0.2 \%$, lactic acid는 $0.1 \%$ 함유하고 있는 것으로 나타났다. 1 차 발효로 생성된 lactobionic acid를 $0.1 \%$ 넣어 2 차 발 효 진행 후, 그 함량이 $0.2 \%$ 로 2 배 증가하였으며 lactobionic acid 외 에 lactic acid도 생성되는 것을 확인할 수 있었다. 또한 발효 전과 후 를 비교하여 발생하는 peak의 변화는 다양한 발효 산물이 생성되었 다는 것을 의미하며 lactobionic acid와 lactic acid 외 성분들에 대해 서는 규명이 필요하다.

동일한 함량의 lactobionic acid 용액을 대조군으로 하여 F-PHA 와 피부 효능을 비교 평가하였으며, lactobionic acid 용액과 비교하 여 F-PHA에서 우수한 DPPH 소거능, 히알루론선 생성 촉진, 프로 콜라겐 type -1 생성 촉진 효과가 있는 것으로 나타났다. F-PHA와 동일한 함량으로 lactobionic acid 용액을 처리하면 용액 내 함유된 lactobionic acid 함량은 DPPH 소거능 평가 시에 $0.004 \%$, 세포 내 효능 평가 시에 $0.0005 \%$ 로 매우 적은 양으로 확인된다. $\mathrm{F}-\mathrm{PHA}$ 에 서 확인된 다양한 피부 효능은 lactobionic acid가 아닌 발효로 인해 발생한 신규 물질에 의한 것으로 해석된다. 항노화 및 보습 효과를 가지는 제품 내 lactobionic acid 함량을 현재 사용하는 농도보다 낮 은 농도로 사용하여도 우수한 효과가 나올 것으로 기대되며 관련하 여 임상 연구가 진행 중이다.

Lactobionic acid 함량을 2 배 증가시키며 추가 발효 산물을 생성해 내는 프로바이오틱스 유산균인 L. Plantarum J2K-27 균주를 이용 한 이러한 이중발효 공법은 기존의 하이드록시산의 생성 증대와 발 효 선물에 의한 피부 시너지 효과를 발휘할 수 있는 기술임을 확인하 였다.

본 연구를 통해 F-PHA의 lactobionic acid와 lactic acid에 의한 각질제거 효과는 물론, 항산화, 보습, 항노화 효과가 있는 기능성 소 재로서 활용 가능함을 확인할 수 있었다.

\section{Acknowledgements}

본 연구는 중소벤처기업부와 산업통상자원부가 지원하는 월드 클래스300프로젝트R\&D (S2525362) 지원사업을 통해 수행된 연 구결과이며, 이에 감사드립니다.

\section{Author's contribution}

MS and JWK contributed equally to this work. MS, JWK, $\mathrm{KB}$, IN, and HS designed all experimental investigations. MS, JWK, KB, JHK, and HS developed the process for the 
analyzed data and wrote the manuscript. IN, KS, TK, YC, HDC, and HEC designed the overall experiments together. All authors read and confirmed the final version of the manuscript.

\section{Author details}

Mikyung Sung (Research Engineer), Creative Innovation Research Center, Cosmecca Korea, Co. Ltd., 6th Floor, ABN Tower, 331 Pangyo-ro, Bundang-gu, Seongnamsi, Gyeonggi-do 13488, Korea; Jungwook Kang (Assistant Professor), Industry-Academic Collaboration Foundation, Seowon University, 377-3 Musimseoro, Seowon-gu, Cheongju, Chungbuk, 28674, Korea; Kitae Bang (Research Engineer), Creative Innovation Research Center, Cosmecca Korea, Co. Ltd., 6th Floor, ABN Tower, 331 Pangyo-ro, Bundang-gu, Seongnam-si, Gyeonggi-do 13488, Korea; Jinhyun Kim (Research Engineer), Creative Innovation Research Center, Cosmecca Korea, Co. Ltd., 6th Floor, ABN Tower, 331 Pangyo-ro, Bundang-gu, Seongnamsi, Gyeonggi-do 13488, Korea; Inyoung Na (Principal Research Engineer), Creative Innovation Research Center, Cosmecca Korea, Co. Ltd., 6th Floor, ABN Tower, 331 Pangyo-ro, Bundang-gu, Seongnam-si, Gyeonggi-do 13488, Korea; Hungi Seo (Principal Research Engineer), Creative Innovation Research Center, Cosmecca Korea, Co. Ltd., 6th Floor, ABN Tower, 331 Pangyo-ro, Bundang-gu, Seongnam-si, Gyeonggi-do 13488, Korea; Kyeongseok So (Principal Research Engineer), Creative Innovation Research Center, Cosmecca Korea, Co. Ltd., 6th Floor, ABN Tower, 331 Pangyo-ro, Bundang-gu, Seongnam-si, Gyeonggido 13488, Korea; Taehoon Kim (Research Fellow), Creative Innovation Research Center, Cosmecca Korea, Co. Ltd., 6th Floor, ABN Tower, 331 Pangyo-ro, Bundang-gu, Seongnam-si, Gyeonggi-do 13488, Korea; Youngkwon Cha (Director), Creative Innovation Research Center, Cosmecca Korea, Co. Ltd., 6th Floor, ABN Tower, 331 Pangyo-ro, Bundang-gu, Seongnam-si, Gyeonggi-do 13488, Korea; Hyundae Cho (Executive Director), Creative Innovation Research Center, Cosmecca Korea, Co. Ltd., 6th Floor, ABN Tower, 331 Pangyo-ro, Bundang-gu, Seongnam-si, Gyeonggi-do 13488, Korea; and Hangeui Cho (Research Fellow), Creative Innovation Research Center, Cosmecca Korea, Co. Ltd., 6th Floor, ABN Tower, 331 Pangyo-ro, Bundang-gu, Seongnam-si, Gyeonggi-do 13488, Korea.

\section{References}

Ahn HY, Park KR, Kim YR, Cha JY, Cho YS. Chemical characteristics in fermented Cordycepin-enriched Cordyceps military. Journal of Life Science, 23: 10321040, 2013.

Algiert-Zielińska B, Mucha P, Rotsztejn H. Comparative evaluation of skin moisture after topical application of $10 \%$ and $30 \%$ lactobionic acid. Journal of Cosmetic Dermatology, 17: 1096-1100, 2018.

Bashir SJ, Dreher F, Chew AL, Zhai H, Levin C, Stern R, Maibach HI. Cutaneous bioassay of salicylic acid as a keratolytic. International Journal of Pharmaceutics, 292: 187-194, 2005.

Edison BL, Green BA, Wildnauer RH, Sigler ML. A polyhydroxy acid skin care regimen provides antiaging effects comparable to an alpha-hydroxyacid regimen. Cutis, 73: 14-17, 2004.

Foti MC. Use and abuse of the DPPH • radical. Journal of Agricultural and Food Chemistry, 63: 8765-8776, 2015.

Green BA, Edison LB, Sigler ML. Antiaging effects of topical lactobionic acid: results of a controlled usage study. Cosmetic Dermatology, 21: 76-82, 2008.

Grimes P, Green BA, Wildnauer RH, Edison B. The use of polyhydroxy acids (PHAs) in photoaged skin. Cutis, 73: 3-13, 2004.

Jo WS, Yang KM, Park HS, Kim GY, Nam BH, Jeong MH, Choi YJ. Effect of microalgal extracts of Tetraselmis suecica against UVB-induced photoaging in human skin fibroblasts. Toxicological Research, 28: 241-248, 2012.

Kang MH, An SM, Kim DH. Physicochemical properties of dried Saururus chinensis and the antioxidative activities of water and $70 \%$ ethanol extracts. Journal of Nutrition and Health, 52: 399-407, 2019.

Kim BG, Oh CK, Jo JH, Lee JB, Kim MB, Jang HS, Kwon KS. Effects of estrogens and isoflavones on the collagen synthesis. Korean Journal of Dermatology, 41: 10411048, 2003.

Kim E, Hwang K, Lee J, Han SY, Kim EM, Park J, Cho JY. Skin protective effect of epigallocatechin gallate. International Journal of Molecular Sciences, 19: 173, 2018.

Kim HS, Choi YH. Comparative study on changes in skin condition according to peeling care techniques. Asian Journal of Beauty and Cosmetology, 16: 82-92, 2018. 
Kim JH, Kim KL. Study on the characteristics of fermented Rhus verniciflua stem bark (FRVSB) as a cosmetic raw material. Asian Journal of Beauty and Cosmetology, 13: 559-567, 2015.

Lee SG, Yoon MS, Kim DH, Shin JU, Lee HJ. Hyaluronan oligosaccharides improve rosacea-like phenotype through anti-inflammatory and epidermal barrier-improving effects. Annals of Dermatology, 32: 189-196, 2020.

Ngamwongsatit P, Banada PP, Panbangred W, Bhunia AK. WST-1-based cell cytotoxicity assay as a substitute for MTT-based assay for rapid detection of toxigenic bacillus species using $\mathrm{CHO}$ cell line. Journal of Microbiological Methods, 73: 211-215, 2008.

Park YE, Kwon GS, Kim BH, Lee JB. Evaluation of the usefulness of the fermented thistle (Cirsium japonicum) with Lactobacillus rhamnosus BHN-LAB105 for antioxidative and whitening effects. Asian Journal of Beauty and Cosmetology, 17: 1-13, 2019.

Pervez S, Aman A, Iqbal S, Siddiqui NN, Qader SAU. Saccharification and liquefaction of cassava starch: an alternative source for the production of bioethanol using amylolytic enzymes by double fermentation process. BMC biotechnology, 14: 1-10, 2014.

Pinto C, Pinho D, Cardoso R, Custódio V, Fernandes J, Sousa S, Pinheiro M, Egas C, Gomes AC. Wine fermentation microbiome: a landscape from different Portuguese wine appellations. Frontiers in microbiology, 6: 905, 2015.

Song BN, Lee DB, Lee SH, Park BR, Choi JH, Kim YS, Park SY. Physicochemical properties and antioxidant activity of extract from Astragalus membranaceus Bunge leaf fermented with lactic acid bacteria. Korean Journal of
Medicinal Crop Science, 28: 428-434, 2020.

Tang SC, Yang JH. Dual effects of alpha-hydroxy acids on the skin. Molecules, 23: 863, 2018.

Tasic-Kostov M, Savic S, Lukic M, Tamburic S, Pavlovic M, Vuleta G. Lactobionic acid in a natural alkylpolyglucosidebased vehicle: assessing safety and efficacy aspects in comparison to glycolic acid. Journal of Cosmetic Dermatology, 9: 3-10, 2010.

Tesfaye W, Morales M, Garcia-Parrilla M, Troncoso A. Wine vinegar: technology, authenticity and quality evaluation. Trends in Food Science \& Technology, 13: 12-21, 2002.

Tsukahara M, Shinzato N, Tamaki Y, Namihira T, Matsui T. Red yeast rice fermentation by selected Monascus sp. with deep-red color, lovastatin production but no citrinin, and effect of temperature-shift cultivation on lovastatin production. Applied Biochemistry and Biotechnology, 158: 476-482, 2009.

Um JN, Min JW, Joo KS, Kang HC. Antioxidant, antiwrinkle and whitening effect of fermented extracts of Hwangryunhaedoktang. Journal of Society of Cosmetic Scientists of Korea, 43: 69-78, 2017.

Varani J, Spearman D, Perone P, Fligiel SE, Datta SC, Wang ZQ, Shao Y, Kang S, Fisher GJ, Voorhees JJ. Inhibition of type I procollagen synthesis by damaged collagen in photoaged skin and by collagenase-degraded collagen in vitro. The American Journal of Pathology, 158: 931-942, 2001.

Yang J, Kwak C. Inhibitory effect of Aralia elata ethanol extract against skin damage in UVB-exposed human keratinocytes and human dermal fibroblasts. Journal of Nutrition and Health, 49: 429-436, 2016. 


\section{국문초록}

\section{Lactobacillus plantarum J2K-27 균주를 이용한 PHA 배양물의 이화학적 특성}

성미경 ${ }^{1}$, 강정욱 ${ }^{2}$, 방기태 $^{1}$, 김진현 ${ }^{1}$, 나인영 ${ }^{1}$, 서훈기 ${ }^{1}$, 소경석 ${ }^{1,3}$, 김태훈 ${ }^{1}$, 차영권 $^{1}$, 조현대 ${ }^{1}$, 조항의 ${ }^{1,3^{*}}$ ${ }^{1}$ (주)코스메카코리아 CIR연구센터, 경기도 성남시, 한국

${ }^{2}$ 서원대학교 산학협력단, 충청북도 청주시, 한국

${ }^{3}$ 건국대학교 화장품공학과, 서울, 한국

목적: 본 연구는 Lactobacillus plantarum J2K-27 (L. Plantarum J2K-27) 유산균을 발효한 폴리하이드록시산(PHA)의 변화를 분 석하고 그 효능을 통해 화장품 소재로서 가능성을 확인해보았다. 방법: L. Plantarum J2K-27 균주를 이용한 PHA의 발효에 의한 성분변화를 확인하고자 고성능 액체 크로마토그래피(HPLC) 분석을 진행하였다. 발효된 PHA의 항산화 효능 및 세포생존율을 측 정하고 히알루론산 및 프로콜라겐 type 1 생성량 측정을 통해 화장품 소재로 가능성을 확인하였다. 결과: HPLC 분석 결과, 발효된 PHA는 락토바이오닉산(lactobionic acid)과 젖산(lactic acid)의 성분을 생성하는 것을 확인할 수 있었다. 또한, 발효된 PHA는 농도 의존적으로 항산화 효과를 나타내었으며, 세포 독성이 없는 농도에서 프로콜라겐 및 히알루론산의 생성량이 농도 의존적으로 증가 하는 것이 확인 되었다. 결론: 본 연구 결과를 종합하여, L. Plantarum J2K-27 균주를 이용한 PHA는 lactobionic acid과 lactic acid 의 성분을 생성하면서 기능성 화장품 소재로서 가능성이 있음을 확인하였다.

핵심어: 폴리하이드록시산, 락토바이오닉산, 젖산, 발효, 화장품 소재

본 연구는 중소벤처기업부와 산업통상자원부가 지원하는 월드클래스300프로젝트 R\&D (S2525362) 지원사업을 통해 수행된 연구 결과이며, 이에 감사드립니다.

\section{참고문헌}

강명화, 안수미, 김도희. 덖음온도를 달리하여 전저리한 삼백초 건조물의 이화학적 특성 및 물과 $70 \%$ 에탄올 추출물의 항 산화효과. Journal of Nutrition and Health, 52: 399-407, 2019.

김병균, 오창근, 조주현, 이재봉, 김문범, 장호선, 권경술. 에스트로겐과 Isoflavone이 교원질 합성에 미치는 영향. 대한피

부과학회지, 41: 1041-1048, 2003.

김정현, 김금란. 화장품 소재로서의 발효 옻 추출물에 관한 특성연구. 아시안뷰티화장품학술지, 13: 559-567, 2015.

김희숙, 최영희. 박피 방법에 따른 피부 상태 변화에 관한 비교 연구. 아시안뷰티화장품학술지, 16: 82-92, 2018.

박예은, 권기석, 김병혁, 이중복. Lactobacillus rhamnosus BHN-LAB105를 이용한 발효 엉겅퀴의 항산화 및 미백효과

에 대한 유용성 평가. 아시안뷰티화장품학술지, 17: 1-13, 2019.

송빛나, 이다빈, 이성현, 박보람, 최지호, 김용석, 박신영. 유산균으로 발효한 황기 잎 추출물의 이화학적 특성 및 항산화

활성. 한국약용작물학회지, 28: 428-434, 2020.

안희영, 박규림, 김유라, 차재영, 조영수. 발효 동충하초의 이화학적 특성. 생명과학회지, 23: 1032-1040, 2013.

양지원, 곽충실. 두릅순 에탄올 추출물의 인간유래 피부각질형성세포와 피부섬유아세포에서의 자외선에 의한 광노화 억제 효과. Journal of Nutrition and Health, 49: 429-436, 2016.

엄지나, 민진우, 주광식, 강희철. 황련해독탕 발효물의 항산화, 항주름 및 미백 효과. 대한화장품학회지, 43: 69-78, 2017. 


\section{中文摘要}

\section{植物乳杆菌J2K-27菌株发酵多羟基酸（PHA）的理化特性}

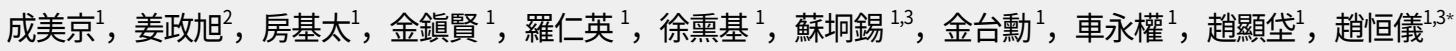

${ }^{1}$ Cosmecca Korea CIR研究中心，京畿道城南市，韩国

2西原大学产学合作基金会，忠清北道清州市，韩国

建国大学化妆品工学科, 首尔, 韩国

目的: 本研究旨在研究植物乳杆菌J2K-27菌株的发酵多羟基酸(F-PHA)的特性, 并确定其生物化合物的适用性。 方法: 使用高效液相色谱(HPLC)分析F-PHA, 以确定其活性化合物。此外, 测量了发酵的PHA的抗氧化功效和细 胞活力, 并且通过测量所产生的透明质酸和1型胶原原的量来确认了作为化妆品材料的潜力。结果: HPLC分析的 结果, 证实了发酵的PHA产生了乳糖酸和乳酸的组分。另外, 发酵的PHA以浓度依赖性方式显示抗氧化作用, 并且证实了在没有细胞毒性的浓度下前胶原蛋白和透明质酸的产生量以浓度依赖性方式增加。结论: 这些结果证 实了使用L.Plantarum J2K-27菌株的PHA在生产乳糖酸和乳酸的组分方面具有作为功能性化妆品材料的潜力。

关键词: 聚羟基酸, 乳糖酸, 乳酸, 发酵, 化妆品 